Article

\title{
Inside a Cucuteni Settlement: Remote Sensing Techniques for Documenting an Unexplored Eneolithic Site from Northeastern Romania
}

\author{
Andrei Asăndulesei \\ Interdisciplinary Research Department-Field Science, Arheoinvest Platform, \\ "Alexandru Ioan Cuza" University of Iași, St. Lascăr Catargi 54, 700107 Iași, Romania; \\ andrei.asandulesei@yahoo.com; Tel.: +40-746-884-225
}

Academic Editors: Kenneth L. Kvamme, Richard Gloaguen and Pradad S. Thenkabail Received: 8 September 2016; Accepted: 28 December 2016; Published: 6 January 2017

\begin{abstract}
This paper presents recent results of an integrated non-invasive investigation carried out in a previously unexplored settlement from northeastern Romania, belonging to the last great Eneolithic civilisation of Old Europe, the Cucuteni-Trypillia cultural complex. Although there is a long history of research concerning this culture, at only a handful of sites has archaeological research completed a comprehensive planimetric image. This makes it impossible to determine a typological evolution of the internal organisation of Cucutenian sites, both diachronically, across the three great phases of the culture (A, A-B and B for the Romanian area), and spatially, from SE Transylvania to the Republic of Moldova, and towards the steppes of the Ukraine. Accordingly, in certain environmental conditions, many essential behavioural aspects of Cucutenian communities are far from understood. Consequently, the generalisation and integration of non-invasive prospecting methods-Light Detection and Ranging (LiDAR), aerial photography, earth resistivity, magnetometry, and their integration through Geographic Information System (GIS)—clearly represents a feasible alternative for deciphering the Cucuteni culture. These complementary investigation methods were applied for this case study, emphasis being put on the conjoint use of datasets from each technique. On the basis of results recently obtained from the Războieni-Dealul Mare/Dealul Boghiu site, innovative characteristics are described concerning intra-site spatial organisation, a typology of the fortification systems, the existence of ritual or delimitation ditches, and the presence of habitations outside fortified areas.
\end{abstract}

Keywords: ALS data; aerial images; geophysics; Eneolithic; intra-site spatial organisation; Cucuteni-Trypillia cultural complex; northeastern Romania

\section{Introduction}

The Cucuteni culture, regarded as the last great Eneolithic civilisation of Old Europe [1-3], has been investigated since the 19th century. The culture is part of the notable Cucuteni-Trypillia Cultural Complex, which stretches from southeastern Transylvania to northeastern Romania, the Republic of Moldova, and to the forest-steppe of the Ukraine, covering a surface of approximately $350,000 \mathrm{~km}^{2}$ [3]. From a chronological point of view, the culture's evolution spans from 4600 to 3600/3500 cal BC [4,5] in the Romanian area. This interval is mostly known for fine, good-quality pottery, predominantly with polychrome painting [3,6], and also for anthropomorphic wares, revealing the sophisticated artistic and aesthetic ideas held by these communities [7]. There are more than 1800 sites on Romanian territory, whether hilltop or lowland settlements, compact or scattered, seasonal or permanent, main or secondary, small, medium or large in size, clearly showing the extremely dynamic character of these communities $[3,8]$. 
Although there is a long history of research concerning this culture and numerous trial excavations have been made (though of limited scale), in many settlements that chronologically span three great phases $(\mathrm{A}, \mathrm{A}-\mathrm{B}, \mathrm{B})$, in only a handful of sites has archaeological research generated a completed planimetric image (viz. Hăbășești [9], Târpești [10], Trușești [11]). In addition, investigations very rarely were extended outside the natural limits of the settlements, or to the outer complex systems considered to be fortification or delineation works. It is difficult to propose hypotheses concerning the cultural landscape of the Eneolithic period based solely on the minimal information gathered almost exclusively from archaeological excavations. Accordingly, even though there have been discussions regarding these topics $[12,13]$, in certain environmental conditions, a great number of aspects essential for understanding the behaviour of the Cucutenian communities are far from known. The internal organisation of these settlements within Romanian territory can be categorised on the basis of whether occupation structures occur in rows, groups, circles or are scattered [8]; by how fortification/delineation systems vary; or by the presence of occupation structures outside of the defensive or ritual structures.

Considering the above, the generalisation for the Cucuteni culture of non-invasive investigations based on integrating the main prospecting methods (aerial photography and geophysical surveying) represents a practical approach for interpreting many of the aspects mentioned above. It also provides new opportunities for understanding the complex evolution of the Cucutenian and other prehistoric settlements.

Previous initiatives concerning Cucuteni culture exist, some undertaken by our team [14-16], by foreign research teams in collaboration with Romanian ones [17], or by groups from other national research centres $[18,19]$. Nevertheless, their results offer no clear conclusions concerning internal organisation were formulated, mainly due to the fact that surveys were only partially made (depending on the accessibility of the area), or that the studied settlements were multicomponent. The latter made it difficult to assign detected anomalies to a specific culture or phase, and also to carry out planimetric interpretations.

New results have been obtained in a case study investigated as part of the Prospect research project, carried out by a team from the Arheoinvest Platform of the Interdisciplinary Research Department from the "Alexandru Ioan Cuza" University of Iași, Romania. The main objective of this paper is a reassessment and reinterpretation of extant discussions in the dedicated literature concerning the internal organisation, fortifications, delineations, ritual elements, and the existence of exterior occupations in Cucutenian sites, and to advance new hypotheses about these topics. In our remote sensing investigations of Războieni-Dealul Mare, we attempted to obtain indications of the settlement that were as clear and as comprehensive as possible. The results are remarkable and have come to represent the Eneolithic of Romania and elsewhere. Additional objectives were a coherently integrated database, obtained by using a variety of prospection techniques, and an emphasis on the effectiveness of an open and integrated model of non-invasive research in studying prehistoric sites in Romania.

\section{Study Area}

Our case study is represented by the Eneolithic settlement of Războieni-Dealul Mare/Dealul Boghiu, belonging to phase A of the Cucuteni culture, located in northeastern Romania in Iași County (Figure 1A). The site is also known from newer studies $[8,20]$ under the name Filiași-Dealul Mare or Dealul Boghiului. It is located in the territory of the village of Războieni, Ion Neculce commune, on the border with Filiași village (Figure 1B). The settlement is located on a promontory running in a NW-SE direction (Figure 1C), strongly affected by active landslides [21-23] (Figure 2A,B). The promontory is situated approximately $500 \mathrm{~m}$ south of the village of Filiași, on the right bank of the Valea Oilor/Recea brook (a left-bank tributary of Bahluieț River), part of the Prut catchment basin. The Valea Oilor brook forms a loop in this area, surrounding the promontory along three of its sides. The geographic coordinates are $47^{\circ} 15^{\prime} 07^{\prime \prime} \mathrm{N}$ and $27^{\circ} 02^{\prime} 27^{\prime \prime} \mathrm{E}$. The absolute elevation is $185 \mathrm{~m}$, and the relative one $85 \mathrm{~m}$. The Valea Oilor basin is home to a high density of Eneolithic sites, 28 of which belong to the Cucuteni culture [24]. Prior to our investigations, this site was investigated only superficially. The fact 
that the archaeological deposits apparently were not very disturbed further encouraged us to select it for our investigations. At the same time, the high degradation of the site strongly affected by natural (mass movement, erosion) and anthropogenic disturbances [20-23] (Figure 2A,B) provided the main incentive for choosing it as our case study.

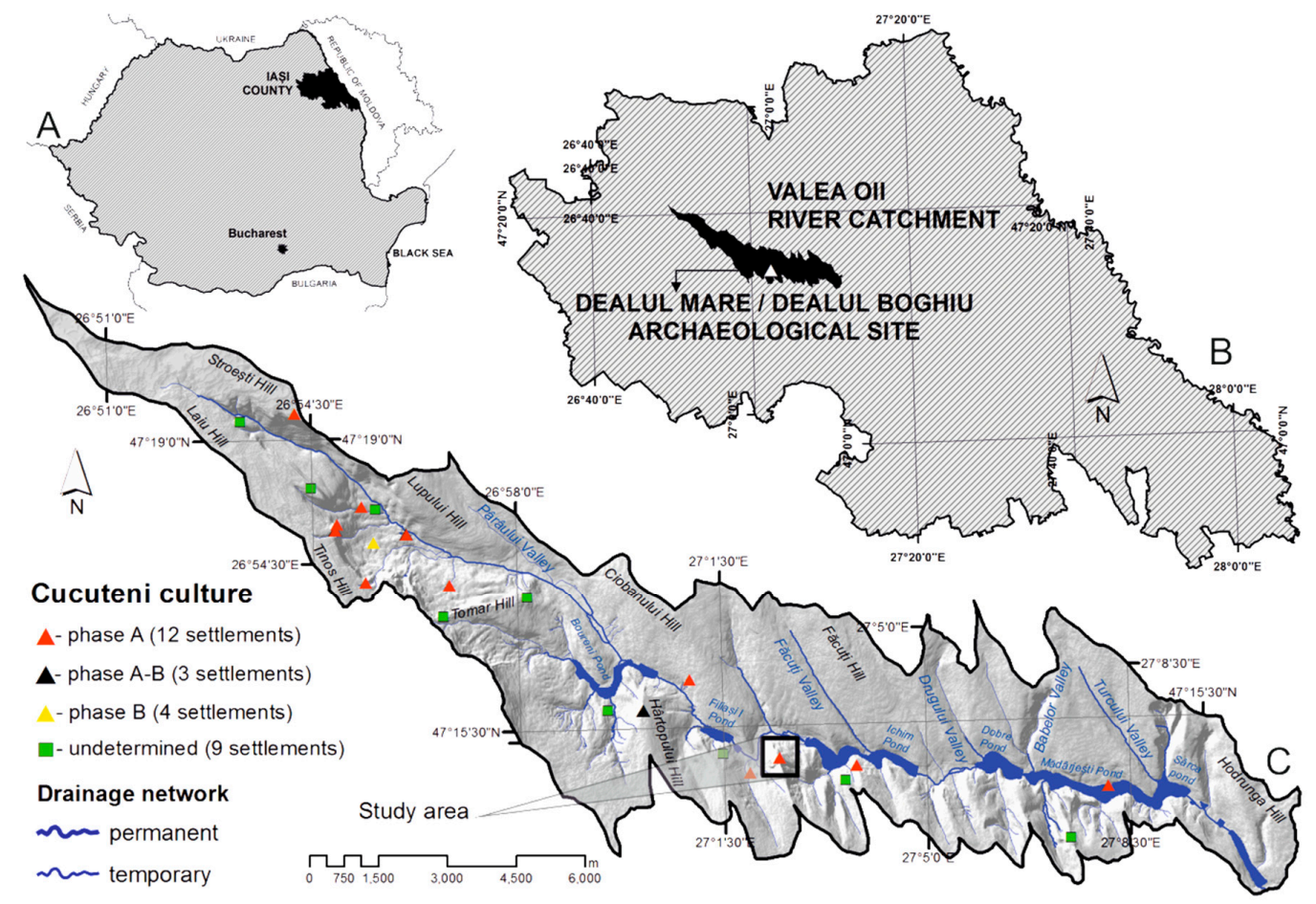

Figure 1. The location of the study area in Romania (A), Iași County (B) and the Valea Oii basin (C); (2.5 m/pixel resolution Digital Elevation Model (DEM) and hydrological network-Nicu, C.).

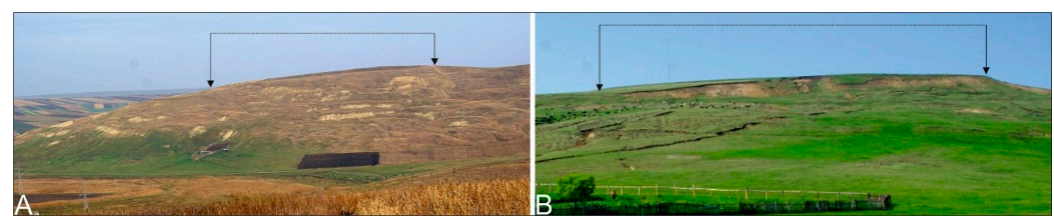

Figure 2. Eastward (A) and Westward (B) views of the Dealul Mare/Dealul Boghiu archaeological site (photo: Nicu, C.).

Războieni-Dealul Mare/Dealul Boghiu was first investigated in 1930s through trial pits by Tafrali, O., Manoliu, V. and Condurache, E. who mention that "pieces from the collapsed walls of the dwellings" [25] were found less than half a meter from the surface. The site was later investigated through fieldwalking in 1955 by Zaharia, N. and Berlescu, N. [26], and in 1984-1986 by Boghian, D. and Mihai, C. [27]. The abundant archaeological material collected from field surveys, comprising trichrome painted ceramic fragments, stone tools and anthropomorphic figurines, date the site to the A3 sub-phase of the Cucuteni culture.

\section{Methodology and Data Acquisition}

The methodological approach for investigating Dealul Mare/Dealul Boghiu was based on ALS (Airborne Laser Scanning) measurements, aerial photographs and geophysical prospection (soil electrical resistivity, total field and vertical gradient magnetometry) and their integration, analysis and interpretation in a Geographic Information System (GIS) environment. Published materials and field survey data were also employed. Such a methodology, based on the integration of the main 
non-invasive prospecting methods, is weakly represented in Romanian archaeology [28,29], even though it has justifiably become a cornerstone of archaeological research worldwide. Ample literature describes such studies. Many have become reference works [30-34] that list associated scientific principles important to archaeologists and amateurs alike. They demonstrate good practices in applying non-destructive techniques [35], and offer case studies with notable results [36-38]. In our research, we chose this approach to ensure that we can detect most types of cultural anomalies since the contrast displayed by the archaeological structures, as well as the signatures generated by them, differ according to the prospecting method employed, climatic, environmental conditions, and other factors.

\subsection{Airborne Laser Scanning (ALS) Data}

The Digital Elevation Model (DEM) [39-41] provides important information regarding the micro-topography of the study area at a scale with more detail than topographic maps and plans, and concurrently offers the opportunity to generate clear imagery of places where the prehistoric communities settled. In our project, the DEM (Figure 3) of an extended area was obtained using ALS data with 4 points $/ \mathrm{m}^{2}$ resolution, which permitted computation of the geomorphological parameters (hypsometry, slopes) of the area neighbouring the site to identify visible cultural anomalies on the settlement's surface. However, the Light Detection and Ranging (LiDAR) data were mainly used to identify natural and anthropogenic hazards that affect the landform upon which the settlement is located.

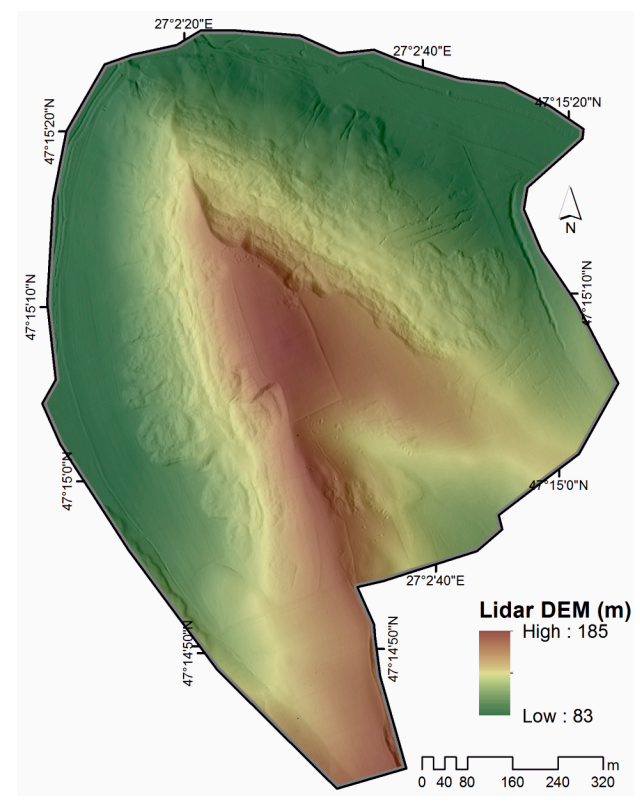

Figure 3. DEM produced from the Airborne Laser Scanning (ALS) data.

\subsection{Oblique and Vertical Aerial Photography}

Aerial photography is predominantly employed to identify new sites on the basis of chromatic indicators visible across the ground surface (crop marks, soil marks, shadow marks, snow marks). Its important role in other research stages (for site documentation, monitoring or interpretation) should not be minimised [42-45]. The 2005 and 2008 editions of orthophoto plans were consulted in the first stage of our research, but since their resolution is poor $(5 \mathrm{~m} /$ pixel), a number of flights were made using a light sport aircraft (Figure 4A) at the end of April 2012 and the last third of May 2015. Over 600 photographs were taken from 15 prehistoric sites, including Dealul Mare, at different times of day and altitudes. For Dealul Mare, two other flights were made using an unmanned aerial vehicle (UAV) (a DJI S1000+ octocopter) fitted with a Canon 5D Mark III camera with a $24 \mathrm{~mm}$ lens (Figure 4B). Over 500 high-definition colour photographs were taken, both oblique and vertical, which were 
later processed using the structure from motion algorithm available in PhotoScan software (Figure 4C). This permitted a high-resolution orthorectified image $(5 \mathrm{~cm} /$ pixel) tied to the national reference system (Stereographic 1970) using ground control points established by differential GPS measurements [46].

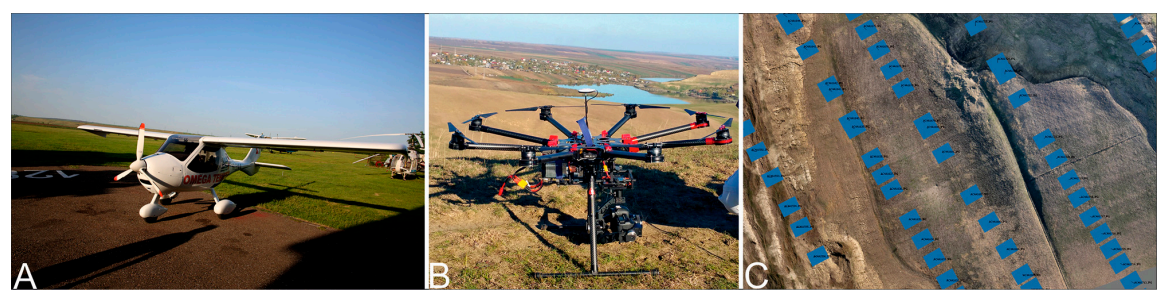

Figure 4. (A) Ultra-light aircraft used for the air surveys; (B) Octocopter with GPS module and gimbal hanging from the main platform; (C) The spatial distribution of the air photographs taken from the UAV.

\subsection{Geophysical Prospection}

Geophysical prospection methods employed in archaeology [47-56] frequently include soil electrical resistivity measurements, caesium-vapour and vertical gradient magnetometry, which are regarded, alongside GPR [57], as the most efficient methods of archaeological prospecting. All except the last were utilised in this study.

\subsubsection{Earth Resistance Survey}

The geophysical surveys began with soil electrical resistivity $[56,58,59]$ testing in the central area of the site, where the presence of a metallic radio antenna and large metallic objects (hooks anchoring the antenna, and a topographic benchmark) ruled out the rest of the non-invasive methods. The survey was carried out using a Geoscan RM15 resistance meter system, one of the most used in such undertakings, deployed in a twin-probe array. There were 16 grids measuring $20 \times 20 \mathrm{~m}$ established, and the distance between the probes was set at $0.5 \mathrm{~m}$, producing a final resolution of $0.25 \times 0.5 \mathrm{~m} /$ pixel. The area covered by the survey was approximately $0.63 \mathrm{ha}$, overlapping the central area of the site (Figure 5). The data obtained was processed with Geoplot software using a "despike" function to remove extreme values, a high-pass filter to diminish geological disturbances, and an edge-matching algorithm for mosaicking the grids.

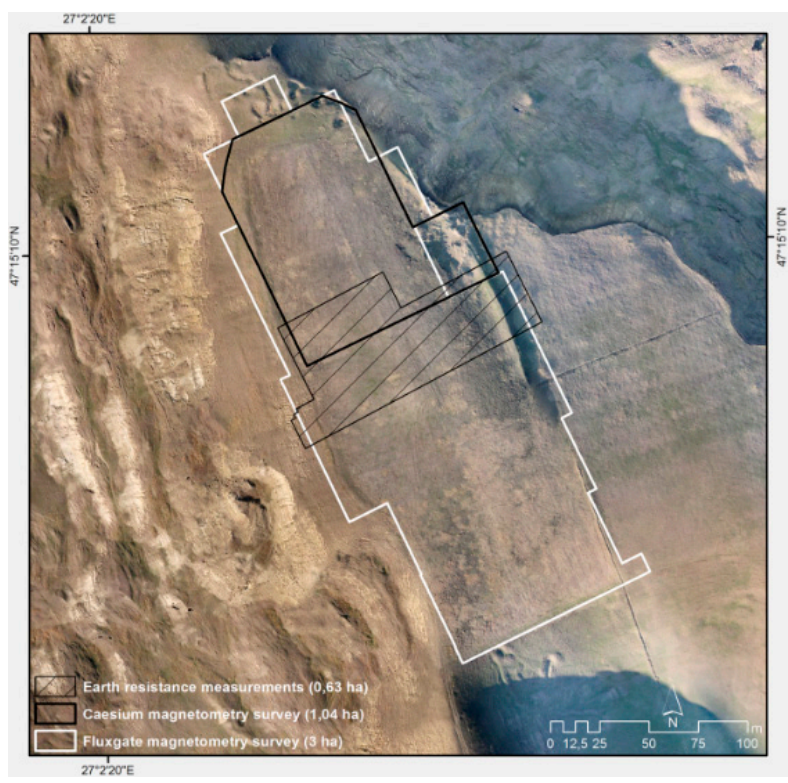

Figure 5. Areas surveyed by means of geophysical techniques. 


\subsubsection{Total Field and Vertical Gradient Magnetometry}

Magnetometry is acknowledged as being among the most efficient methods of archaeological prospecting. It offers precise information regarding the location of underground archaeological structures like ditches, pits, etc., but particularly those that were subjected to fire [60-65]. This category includes the archaeological characteristics regularly identified by excavation in Cucutenian sites [66]. They are found strongly affected by (probably deliberate) fires burning at high temperatures, sometimes vitrified. The strong contrast identifiable through both types of magnetometry explains our predilection for it as the core method.

A series of tests were first conducted in order to determine the most adequate array for our study area. We ultimately selected a duo-sensor configuration for total field measurements, with a distance of $0.5 \mathrm{~m}$ between the probes and a height of approximately $0.2 \mathrm{~m}$ from the ground. A Geometrics G858 (0.05 nT sensitivity) caesium-vapour magnetometer was used for the task. The grid squares measured $40 \times 40 \mathrm{~m}$, and data was collected along transverses in a zigzag pattern with a sampling rate of 10 readings per second. The data were processed using Geometrics' MagMap and MagPick (v. 3.25) software, which aligned the profiles and removed striping, and Geoscan's Geoplot software for creation of the composite grids. Geoplot was also employed to remove the linear diurnal variations using the "deslope" function. The area covered by this survey measured ca. 1 ha, and occupied the northwestern tract of the settlement (Figure 5), where the density of ceramic fragments is very strong.

The results of the caesium measurements were compared with those obtained during tests on a 5-probe-array fluxgate gradiometer using two different configurations $(0.25 \mathrm{~m}$ and $0.5 \mathrm{~m}$ separation between probes). The first was selected with a sampling rate of $0.02 \mathrm{~m}$, which yielded the best possible resolution. The probes were mounted onto a cart at a height of $0.2 \mathrm{~m}$ from the ground. The grid squares were again set at $40 \mathrm{~m} \times 40 \mathrm{~m}$. The data was collected in a zigzag pattern using the odometer part of the Sensys system. The data were imported into Geoplot where the final processing took place. With five probes separated by a distance of $0.25 \mathrm{~m}$, this system is very fast, covering an area of ca. 3 ha (Figure 5) that practically captures the entire enclosure indicated by the aerial imagery.

\section{Geographic Information System (GIS)-Based Data Integration and Interpretation of Results}

The large volume of information obtained by this project was managed through GIS (ESRI ArcGIS 10.2.2 for Desktop, 2014, Environmental Systems Research Institute). The ALS-derived DEM, oblique and vertical aerial photographs, and maps obtained from the magnetometry surveys represent georeferenced thematic layers that were integrated, analysed and interpreted in the GIS environment [67]. GIS thus provided a uniform environment for dealing with these diverse but complimentary data sets.

\subsection{ALS Data Interpretation}

The ALS data included a buffer zone of approximately $600 \mathrm{~m}$ around the site which allowed us to better realise the landform in which our case study is located. The settlement occupies a promontory with a NNW-SSE orientation, shaped on its western, northern and northeastern sides by an ample meander of the Valea Oii brook. The slopes are strongly affected by landslides, their declivity often exceeding $30^{\circ}-35^{\circ}$ (Figure $6 \mathrm{~A}, \mathrm{~B}$ ). The southern side connects the structural plateau on which the settlement is located and the interfluvial ridges that make up the watershed between Valea Oii and the Bahluiet basin. This last area is less affected by geomorphological processes (Figure 7A). These landscape features, with three sides naturally protected by steep slopes with a fourth one open, are frequently documented for the Cucuteni settlements located at higher altitudes, especially during Phase A of the culture [68]. Over time it became obvious that this type of site location had strategic defensive advantages through its dominant position. Additionally, the relative altitude of the landform ( $85 \mathrm{~m}$ high, one of the highest from the catchment) ensured superior visibility of surrounding terrain. 
An anthropogenic structure can be observed on the central plateau on which the site is located. It is an earthen wall enclosure about $15-20 \mathrm{~cm}$ high, which delimits this promontory (Figure 7B, anomaly A1). Because its shape and dimensions are unusual for Cucuteni sites in Romania, we are cautious regarding its cultural attribution. Fierce fighting took place in this area during World War II and the visible structure in the ALS data could date from that period. At the same time, a series of straight, transversal and longitudinal anomalies (linear microrelief anomalies A2, Figure 7B) located inside the enclosure do not seem to belong to the typical Eneolithic pattern found in our area. To the west, in an approximately N-S direction, a quasi-straight anomaly (anomaly A4) connects at the north with the previously mentioned enclosure. It is located in the part of the settlement affected by landslides. We therefore believe it could be an earlier boundary of the site. Another larger anomaly in the northeastern area of the site is represented by a recent anthropic intervention, caused by clay quarrying (anomaly A3).

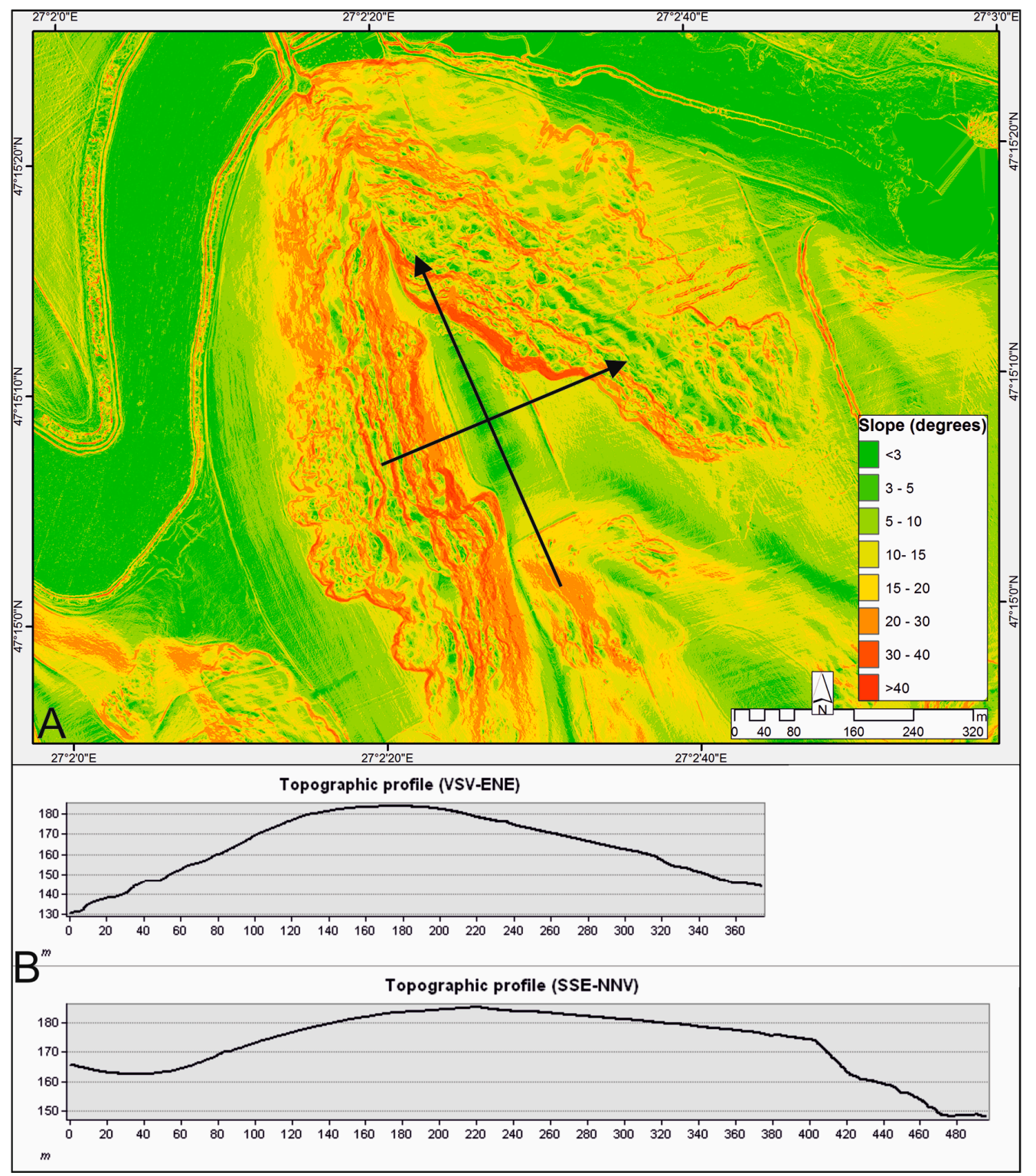

Figure 6. (A) Slope map for the study area; (B) Topographic profiles (transversal and longitudinal along the investigated areas). 

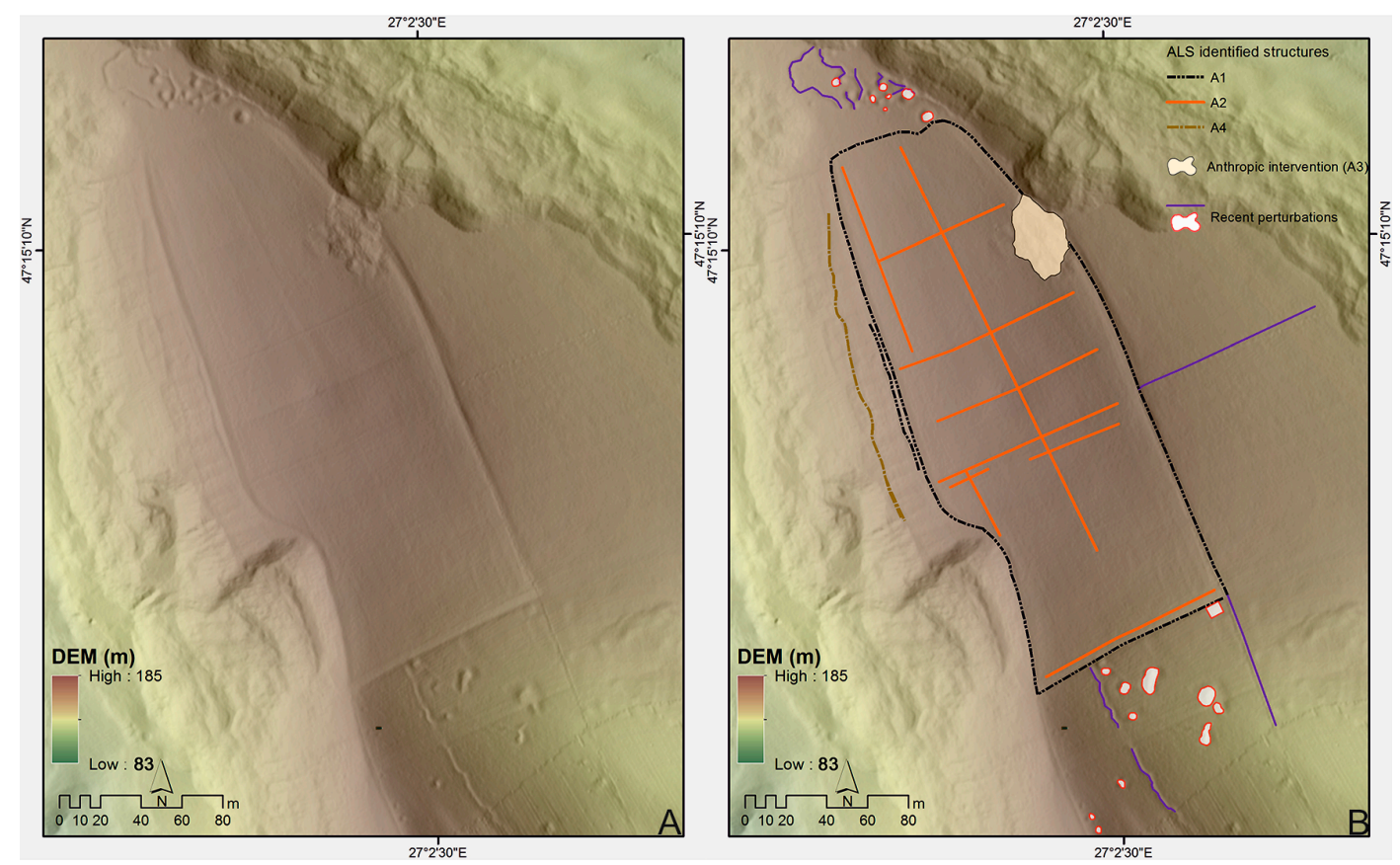

Figure 7. Identified structures in the ALS data: (A) ALS hypsometric map (hill shade superimposed by DEM); (B) The identified features.

\subsection{Oblique and Vertical Aerial Photography}

Multi-faceted analyses were carried out in a GIS environment of the oblique (Figure 8A,B) and vertical aerial photographs (Figure 9B). They were orthorectified, georeferenced, and graphically processed to highlight the presence of several anomalies of different shapes and sizes, many of which were also identified from the ALS data. A cropmark anomaly defines the enclosure that delimits the sides of the promontory (Figure 9B, anomaly P1), as well as the other characteristics or perturbations already identified (anomalies P2, P3 from Figure 9B). The NNW side of the enclosure is better represented in the oblique and vertical photographs than in the ALS-derived DEM.

A series of light-coloured chromatic indicators of different sizes and shapes (Figure 9B) are noticeable throughout the plateau. These crop marks only partially correspond with anomalies identified by the geophysical methods described below. Grazing and strong erosion of the site surface may contribute to the low contrast of these anomalies in the aerial photos. A possible old boundary of the site, visible also in the ALS data, is reconfirmed by the P3 anomaly (Figure 9B) located on the western side of the landslide. The settlement may have been affected by geomorphological processes since its occupation. Also very visible are the scarps and slumps of mass wasting that strongly impact the plateau on the northern, eastern and western sides. These circumstances make it impossible to estimate the initial surface of the site. 

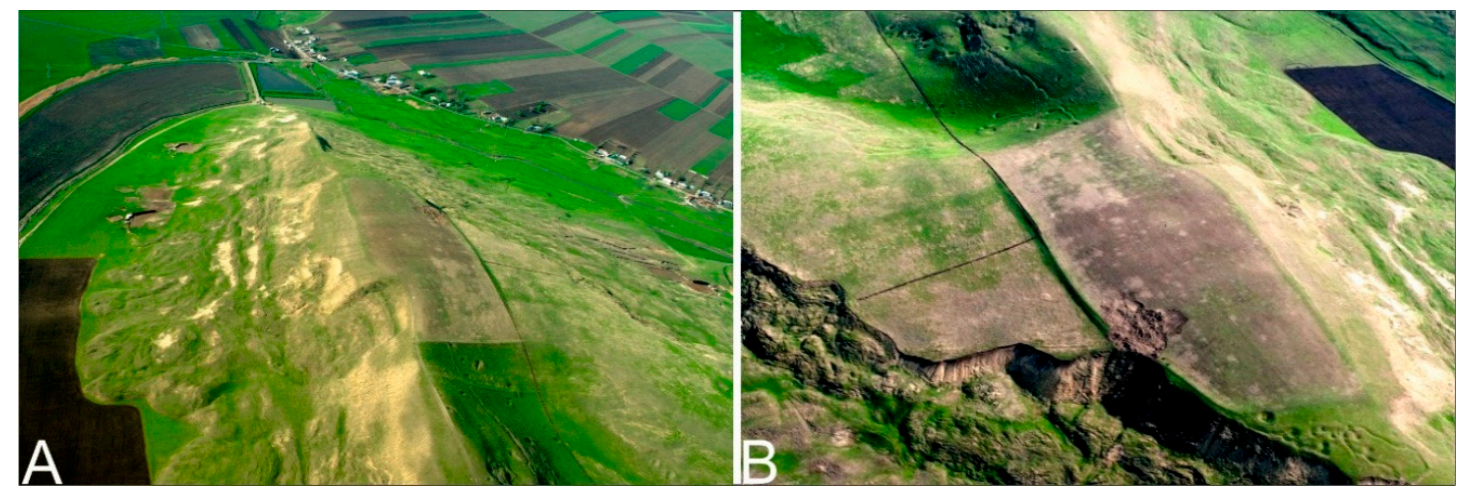

Figure 8. Oblique air photographs: (A) View from the S; (B) view from the NE.
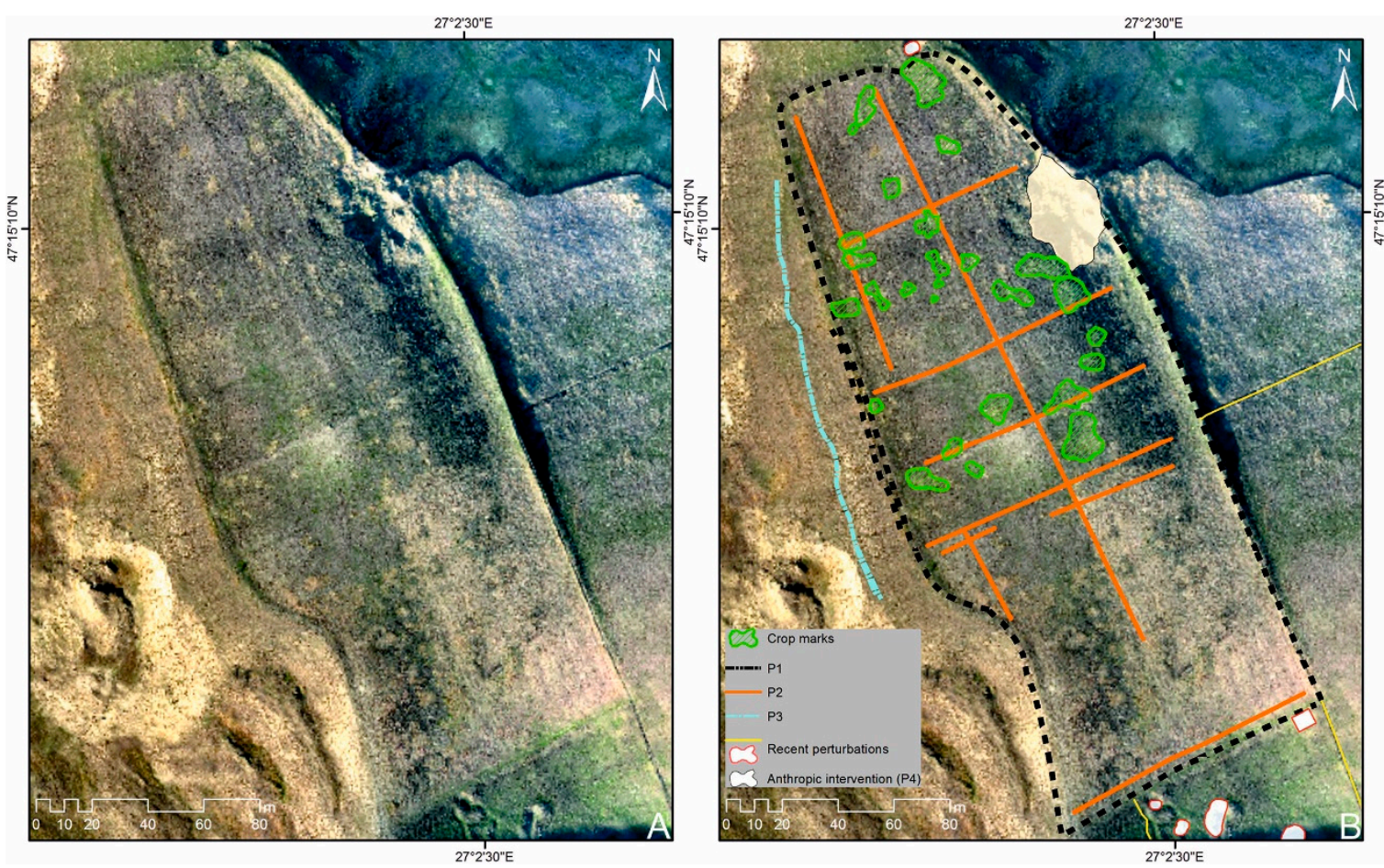

Figure 9. Identifying anomalies in air photographs: (A) Orthorectified air photograph; (B) Features of possible cultural interest.

\subsection{Geophysical Survey}

\subsubsection{Electrical Resistance}

Geophysical prospecting began with a soil electrical resistivity survey (Figure 10A). Approximately 12 rectangular high-resistivity anomalies, apparently without spatial arrangement, were identified in the central area of the settlement. After correlation of this group of anomalies (R1, Figure 10B) with ones detected by magnetometry (described below) we can clearly classify them as indicative of Eneolithic archaeological structures. Two linear structures (the R2 group, Figure 10B,C), also characterised by high resistivity $(>5 \Omega \cdot \mathrm{m})$, were detected along the path of the wall revealed in the ALS-derived DEM and the air photographs, on the ENE and WSW sides of the promontory. 

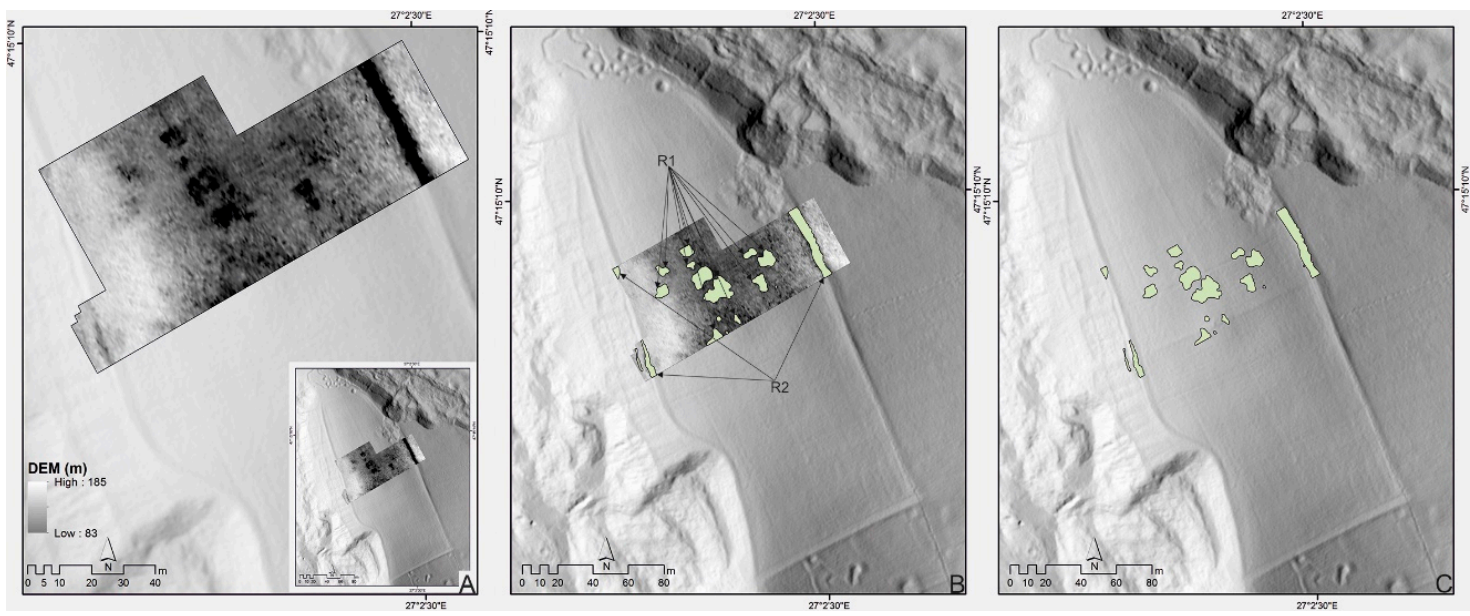

Figure 10. Interpreting the anomalies identified in soil electrical resistivity measurements: (A) High pass filtered earth resistivity data $(-5$ to $+5 \Omega \cdot \mathrm{m})$ overlaid on the digital model from the ALS;

(B) Identifying anomalies; (C) Distribution of anomalies within the study area.

\subsubsection{Total Magnetic Field Measurements}

The caesium magnetometry survey was carried out in the northern half of the promontory, in an area with a high concentration of ceramic fragments. It revealed a multitude of archaeological features (at least 15) as positive anomalies with dipoles aligned parallel to the direction of the Earth's magnetic field (Figure 11A,B). A number of metallic objects were also identified. The archaeological features display a characteristic contrast due to a high magnetic susceptibility, but also from a thermoremanent magnetisation with a signal intensity over $20 \mathrm{nT}$ (Figure 12) [69]. It is very hard to determine an exact count of the number of archaeological structures that might be represented because erosion and landslides in this area have strongly affected the upper deposits.
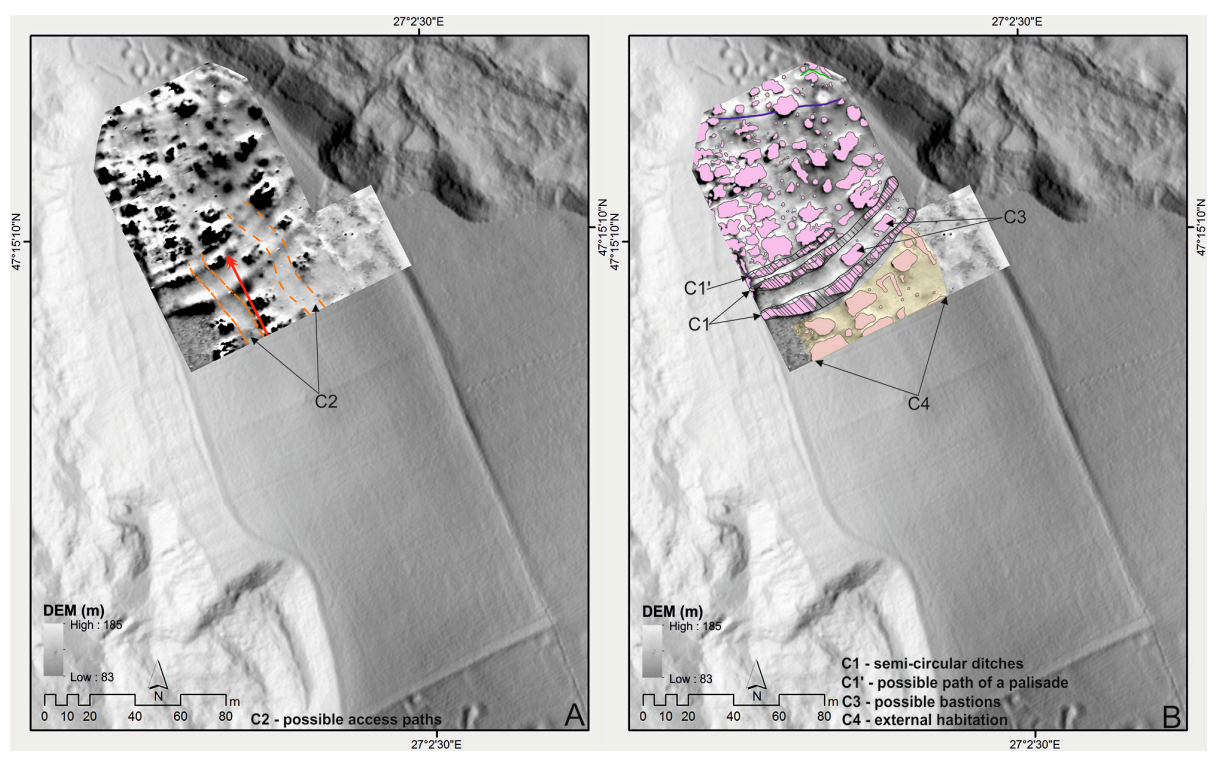

Figure 11. Interpreting the anomalies identified by total field measurements: (A) Magnetic map ( -15 to $+15 \mathrm{nT}$, white to black) overlaid on the DEM from ALS; (B) Anomalies identified.

Countless examples from archaeological excavations in Cucutenian sites exist where the remains of habitation structures bear traces of strong fires. They support the interpretation of the positive anomalies as dwellings, hearths or annexes. Most of them are rectangular in shape of varying sizes 
(most range between 10-13 $\mathrm{m}$ in length, and 5-7 $\mathrm{m}$ in width). A second category of positive anomalies, with lower intensities, can be attributed to pits or ditches which are filled predominantly with organic materials [70,71].

The internal organisation of this site seems to have been well planned, with the dwellings apparently placed in semi-concentric rows in the NNW part of the site. The settlement was defended by steep slopes on all sides, except the SSE one. This open section was fortified with two large parallel semi-circular ditches (the $\mathrm{C} 1$ anomalies in Figure 11B). The width of the two ditches varied from $2 \mathrm{~m}$ to $5 \mathrm{~m}$. Inside, very close to the northern ditch, there seems to be a third one, much narrower than the other two. This is preserved only in the western half and could represent the path of a palisade (anomaly C1' in Figure 11B).

The ditches that close this side of the settlement are interrupted by two access paths (most likely with gates) that head towards the tip of the promontory (Figure 11A, anomalies C2). There are also two rectangular positive anomalies situated between the two large ditches, on both sides of the eastern access path (C3 features). Although their functionality is difficult to define, we think they could be part of a complex defensive system (bastions) associated with the three ditches, since they are positioned without overlapping older structures. This clear separation of each anomaly also argues for their contemporaneity based on their similar shapes and NE-SW orientations. Other positive anomalies are similar and are found to the south of the NNW fortified group (the C4 group in Figure 11B), supporting the view that the area occupied by the settlement expanded at some point.

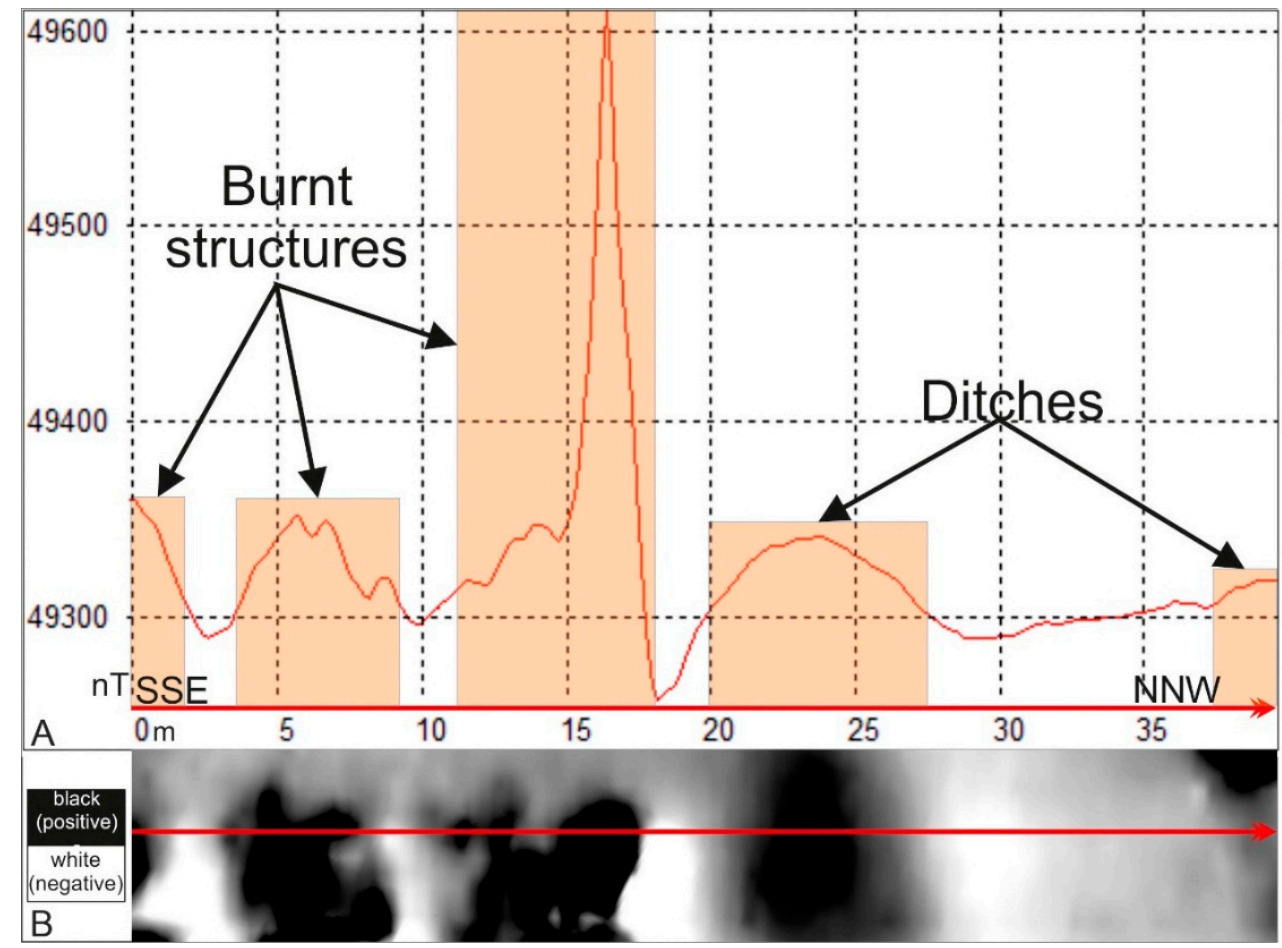

Figure 12. Magnetic profile corresponding to the red line in Figure 11A. Both in the profile (A), and in the plan view representation (B) the strong intensity of anomalies generated by three dwellings and the two large parallel ditches are conspicuous.

\subsubsection{Fluxgate Gradiometry}

The faster rate of data acquisition achieved by fluxgate gradiometry allowed us to cover a more extensive area in the summer campaign of 2015 (Figure 13A,B). The area surveyed included portions already investigated through soil resistivity and caesium magnetometry, and also the SSE part of the enclosure revealed by the ALS-derived DEM and aerial photographs. 

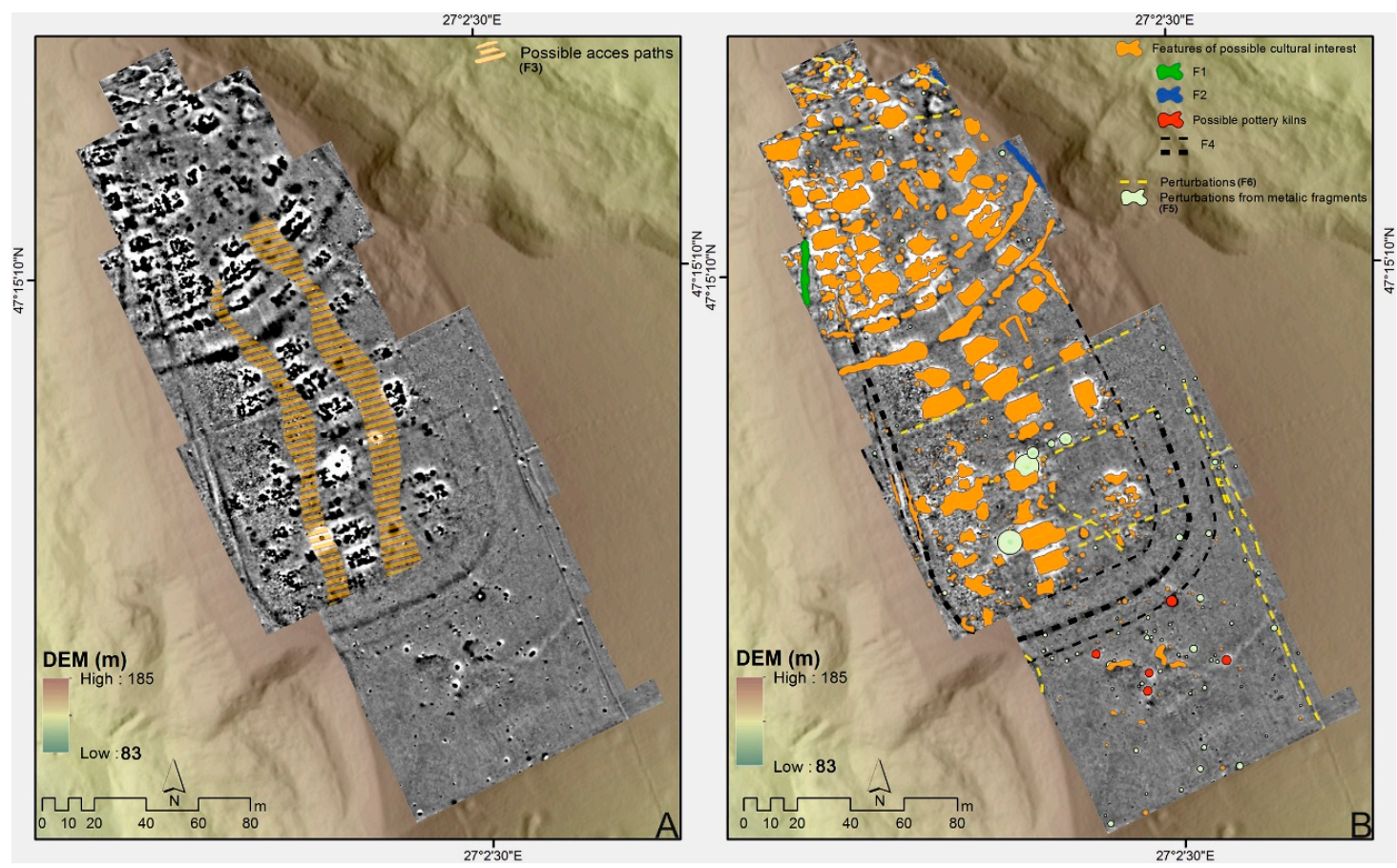

Figure 13. Interpreting the fluxgate data: (A) Fluxgate gradiometer survey ( -10 to +10 , white to black); (B) Identified structures.

No significant differences are discernible between the fluxgate and total field surveys in terms of the locations, shapes, sizes and numbers of anomalies detected in the NNW portion of the settlement. However, the extended fluxgate survey near the margins of the promontory in this region permitted identification of new anomalies. Most notable is a positive one at the western edge of the promontory, appearing as a ca. 25-metre long line (anomaly F1 in Figure 13B), which seems to overlap one detected in the ALS and aerial photographs. This probably represents an older boundary of the settlement, destroyed by hydro-geomorphological processes during occupation. Across the promontory, at the NE edge of the site, there is another linear structure approximately $30 \mathrm{~m}$ long (anomaly F2 in Figure 13B), although with a reduced intensity, that coincides with the enclosure visible in the ALS model and air photographs.

Continuing towards the SSE there are three rows of identified structures indicated by distinct positive anomalies, primarily rectangular in shape. They are divided by the two possible access ways (anomalies F3 in Figure 13A) that cut through the semi-circular ditches fortifying the group of structures in the NNW. These rows of structures, oriented in a NNW-SSE direction, are surrounded by three positive curvilinear anomalies (anomalies F4 in Figure 13B) that are very narrow (approximately between $0.5 \mathrm{~m}$ and $1.5 \mathrm{~m}$ in width). They most probably represent boundary ditches occasioned by the enlargement of the settlement and may have symbolic significance. There are also a few positive anomalies further to the SSE outside of these boundary works, but many are small and dipolar and probably generated by metallic fragments. The identification of some of them as pottery kilns (the red spots in Figure 13B) is possible, on account of their strong magnetisation and orientation. The F5 group of anomalies (Figure 13A), which disturb the area of the rowed structures, likely represents metallic perturbations.

Near the far southern part of the settlement are linear positive anomalies (F6 group in Figure 13B) which do not belong to the Eneolithic site, but most probably reflect recent disturbances. Even though they may appear to exist under the structures assigned to the Cucutenian era in the magnetograms, and thus could be considered older, these anomalies are likely generated by narrow linear ditches dug at shallow depths which do not disturb the archaeological layers. 


\subsection{GIS-Based Interpretation}

The interpretation of all the anomalies identified from one or more methods in a GIS environment offers a detailed image of their shapes, sizes and distributions within the study area (Figure 14a). Even though the site seems to be unstratified, several recent disturbances (clay extraction, intensive grazing, ploughing) muddle our view of the Eneolithic layers. Nonetheless, considering previous discoveries in Cucutenian sites ascertained through excavations or geophysical prospection, and on the basis of a rigorous analysis of all the types of anomalies detected here, a number could be selected to construct a plan map of the Cucutenian site (Figure 14B).
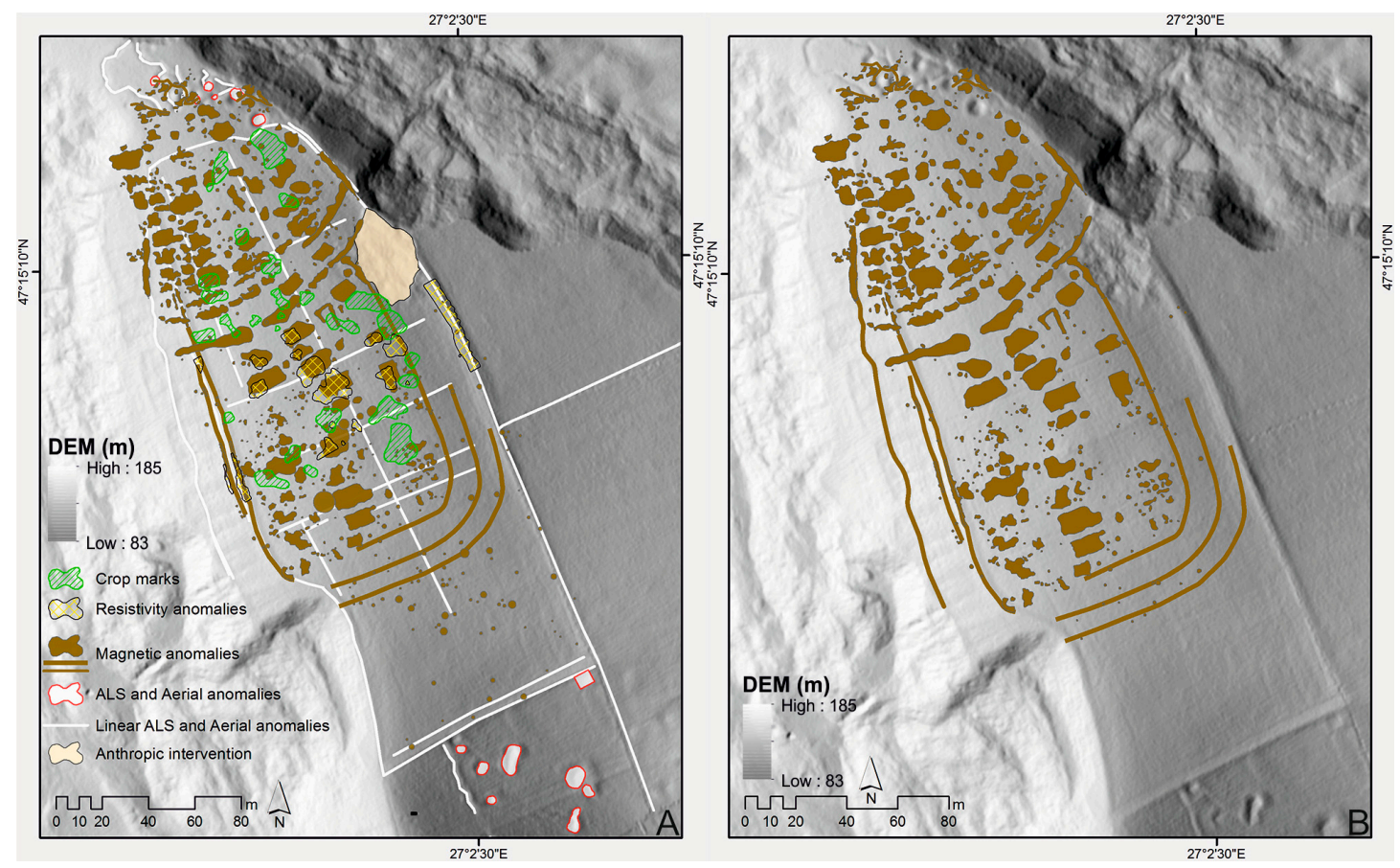

Figure 14. The final integrated interpretation: (A) Distribution within the study area of all anomalies identified using the array of techniques employed; (B) Distribution of anomalies regarded as belonging to the Eneolithic settlement.

\section{Discussion}

Based on these research results, a completely new planimetric organisation of the site of Dealul Mare/Dealul Boghiu has been revealed, different from what was known, until now, from the professional archaeological literature of Romania [3,8,72], the Republic of Moldova [73-75], or from the Trypillia area in the Ukraine [76-78]. The existence of a fortified area in the NNW, with a high density of archaeological structures, certainly represents the initial core of the settlement from which the habitation extended towards the SSE as the number of inhabitants increased. A similar novel evolution was recently observed in magnetometry surveys conducted by our team in the settlement from Ripiceni-Holm, Botoșani County, from the second phase of the Cucuteni culture (A-B) [15].

The buildings in the group towards the NNW of our site are placed in a semicircle, with the highest density in the SW part along the path of the ditches. This type of placement could point to a situation in which the boundary and fortification elements specific to that zone were made before the habitation structures, similar to the Romanian site of Hăbășești [9] which belonged to the same chronological period (Figure 15A,B). A fortification system following the same pattern of two parallel ditches, albeit not dug in the same phase, was documented at Cucuteni-Cetătuia [79], the type-site of the culture. Another very similar and relevant example is the settlement from Brătești-Dealul Chicerea (Figure 15C) where a magnetometry survey revealed three parallel ditches with the inner one 
much narrower [15]. Three parallel ditches were likewise detected through geophysical methods at Fulgeriș-La trei cireși in Bacău County, Romania [14].
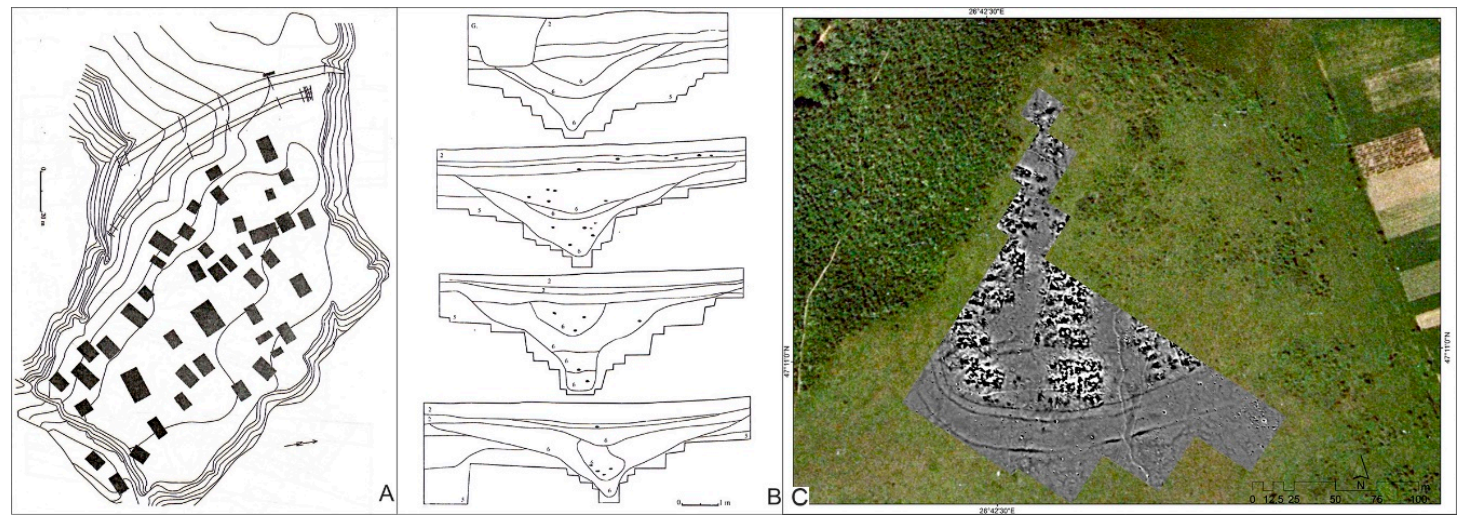

Figure 15. (A) The layout of Hăbășești, Holm [9] archaeological site with two ditches closing the open side of settlement; (B) Cross-sections through the outer ditch from Hăbășești, Holm [9]; (C) Magnetic map ( -10 to $+10 \mathrm{nT}$, white/black) from Brătești, Chicerea [15] showing a similar defensive system composed from two large parallel ditches and a third narrower one.

The strong intensity of the magnetic signal of the two large ditches that protect the congested area in the NNW of Dealul Mare/Dealul Boghiu represents a very clear contrast of magnetic susceptibility. We can state that these works were periodically maintained and cleaned by the inhabitants and were filled only after the occupation of the site ceased, after which the quantity of iron oxide increased markedly. In contrast, the two sections of the ditches in the areas of the pathways to the fortified enclosure, do not illustrate the same intensity, which leads us to believe that these sections were filled intentionally in order to facilitate access. On the other hand, the two rectangular structures positioned between the two large ditches, on each side of the NE pathway, were used as bastions or observation points. It is also possible that the access areas had gates. A somewhat similar situation was documented in the excavation from Traian-Dealul Fântânilor, where traces of so-called observation points and of a footbridge over the ditch were uncovered [80].

Although the settlement is naturally protected by steep slopes on the northern, eastern and western sides, these areas seem to have been enclosed, probably with palisades, perhaps due in part to the risk of people and animals falling down the slopes or to block access of the herds to those areas. Our results also confirm the relocation of the enclosures destroyed by landslides. The free spaces between the existing houses in the NNW section of the settlement, positioned on the main access route, can be also explained through the presence of animal herds that were sheltered here. We can observe similarities concerning the palisade ditches on the edge of the plateau, in the areas with steep slopes, as in the site from Bodești-Frumușica [81]. In order to better understand these open areas, we intend to carry out phosphorus and potassium analyses, which may shed light on the presence of herds in these sectors. Similarly, the acquisition of thermal and near-infrared imagery for the entire site is a complementary task that we hope to carry out.

Another core element of originality in the Cucuteni culture revealed by our results is the presence of consistent habitation outside the main fortified area, with houses placed in three rows in a pattern different from the fortified area. This type of habitation, located outside the defensive system, has been partially revealed in the site at Cucuteni-Cetătuia [79].

In the NNW area of the settlement, the orientation of the houses is difficult to establish due to the intensity of agglomeration of many habitation phases. In contrast, the distribution of structures seems to be clear in the exterior area. At least ten rectangular structures are distinguished that are heavily burned and with a NE-SW orientation. Houses from the exhaustively excavated Romanian Cucuteni sites of Hăbășești [9] and Târpești [10] were also oriented in the same direction. The anomaly 
different to this pattern is the house located in the eastern extremity of the site which is oriented NW-SE. It might represent, on a much smaller scale, a special building similar to those from a number of Trypillia settlements in the Ukraine [82,83].

The habitations outside the fortified area are also surrounded by three parallel curvilinear ditches. While their functionality is difficult to establish, what is certain is that their dimensions (narrower and shallower) prove they did not have a defensive character. Perhaps their role was symbolic and apotropaic, to isolate the settlement. On the other hand, if the ditches are part of a more complex system of palisades, we could similarly suggest them as a method to fortify the site. A similar situation was documented at Ariușd, where a quadruple palisade was placed in the northern area of the site, which was in turn protected by extremely steep slopes [84].

\section{Conclusions}

This study utilises a number of integrated techniques of remote sensing in a novel way (in terms of complexity and diversity) to document for the first time the spatial organisation of an Eneolithic settlement belonging to the Cucuteni-Trypillia cultural complex. New understanding of the behaviour of Eneolithic communities, which are distributed through eastern Romania, the Republic of Moldova, and the Ukraine, are introduced to the professional literature regarding the typology of the fortification systems, the existence of ritual or boundary ditches, and the presence of habitations outside fortified areas.

Interpreting the magnetic maps clearly reveals the evolution of this site throughout the A phase of the Cucuteni culture by identifying an area that could be considered a fortified enclosure, with many layers of habitation that represented the initial core which subsequently expanded as a result of population increase and almost completely covered the plateau area of the hill.

This internal village structure linked with the topography of the site, with well-defined buildings and open spaces, pathways to the fortifications, fortified elements, etc., involved an impressive amount of labour which clearly emphasises the existence of a well-established social organisation, following the rules established within Cucuteni communities. The results of this study, together with those obtained by our team at other Cucutenian sites such as Ripiceni-Holm, Brătești-Dealul Chicera, Fulgeriș-La trei cireși, Hândrești-Dăiceni, etc., with their varied typology of documented internal organisations, shows how they anticipate the later evolution of the mega-sites and giant settlements seen in the Republic of Moldova and Ukraine.

The existence in our case study of a fortified enclosure with semi-circular ditches and palisades in the core area, and the presence of exterior habitations surrounded by three narrow curvilinear ditches, shows a clear distinction that should be made between defensive elements and ones with a symbolic purpose. In other words, our study documents a novel situation that could provide clarifications regarding the functionality of these construction works, a topic that divides the scientific community and offers occasional ungrounded opinions that are intensely debated in the professional literature.

We believe that this type of settlement plan mapping is the first undertaken within the Cucuteni area. Prior archaeological research, except for a few examples, has consisted mainly of making small test excavations focused mainly in the central areas of settlements where major archaeological remains are located. In view of these results, the use of non-invasive investigations in researching Eneolithic sites belonging to the Cucuteni-Trypillia cultural complex now seems mandatory. They permit creation of integrated research results that can significantly contribute to prioritizing the main directions of future work and a reassessment of archaeological excavation strategies.

Acknowledgments: This study was supported by the Partnership in Priority Domains project PN-II-PT-PCCA-2013-4-2234 No. 314/2014 of the Romanian National Research Council, Non-destructive approaches to complex archaeological sites. An integrated applied research model for cultural heritage management. The author would like to thank the "Apele Române" national bureau of water management, Prut-Bârlad branch, for providing us with the LiDAR data. Acknowledgements are also extended towards colleagues within the Arheoinvest Platform for the support provided during the research. 
Conflicts of Interest: The authors declare no conflict of interest. The founding sponsors had no role in the design of the study; in the collection, analyses, or interpretation of data; in the writing of the manuscript, and in the decision to publish the results.

\section{Abbreviations}

The following abbreviations are used in this manuscript:

$\begin{array}{ll}\text { ALS } & \text { Airborne Laser Scanning } \\ \text { GIS } & \text { Geographic Information System } \\ \text { GPS } & \text { Global Positioning System } \\ \text { DEM } & \text { Digital Elevation Model } \\ \text { GPR } & \text { Ground Penetrating Radar } \\ \text { UAV } & \text { Unmanned Aerial Vehicle }\end{array}$

\section{References}

1. Monah, D.; Monah, F. The last great Chalcolithic civilization of Old Europe. In Cucuteni. The Last Great Chalcolithic Civilization of Old Europe; Mantu, C.M., Dumitroaia, G.H., Tsaravopoulos, A., Eds.; Athena Publishing \& Printing House: Bucharest, Romania, 1997; pp. 15-98.

2. Gimbutas, M. The Gods and Goddesses of Old Europe. Myths and Cult Images 7000-3500 BC; University of California Press: Los Angeles, CA, USA, 1974.

3. Lazarovici, C.M.; Lazarovici, G.; Turcanu, S. Cucuteni. A Great Civilization of the Prehistoric World; Editura Palatul Culturii: Iași, Romania, 2009.

4. Mantu, C.M. Cultura Cucuteni. Evoluţie, Cronologie, Relaţii Culturale; Editura Nona: Piatra Neamţ, România, 1998.

5. Bem, C. Noi propuneri pentru o schiţă cronologică a eneoliticului românesc. Pontica 2001, XXXIII-XXXIV, 25-121.

6. Ellis, L. The Cucuteni-Tripolye Culture: A Study in Technology and Origins of Complex Society; Archaeopress: Oxford, UK, 1984.

7. Monah, D. Anthropomorphic Representations in the Cucuteni-Trypolie Culture; Archaeopress: Oxford, UK, 2015.

8. Monah, D.; Șt. Cucoș. Aşezările Culturii Cucuteni din România; Editura Junimea: Iaşi, România, 1985.

9. Dumitrescu, H.; Petrescu-Dîmbovița, M.; Gostar, N. Hăbășești, monografie arheologică; Editura Academiei Române: București, România, 1954.

10. Marinescu-Bîlcu, S. Tîrpești. From Prehistory to History in Eastern Romania; Archaeopress: Oxford, UK, 1981.

11. Dîmbovița, M.P.; Florescu, M.; Florescu, A. Trușești, Monografie Arheologică; Editura Academiei Române: București, România; Iași, România, 1999.

12. Bem, C. Les fortifications de l'aire Precucuteni et Cucuteni. Entre les axiomes et archétypes. Cultură şi Civilizaţie la Dunărea de Jos 2001, XVI-XVII, 53-98.

13. Lazarovici, C.M. Fortificațiile culturii Cucuteni în lumina cercetărilor mai vechi și mai noi. Studii de arheologie. Studia in honorem Doina Ignat 2014, 113-123.

14. Asăndulesei, A.; Istina, L.E.; Cotiugă, V.; Tencariu, F.A.; Caliniuc, Ș.; Balaur, R.; Crețu, A.P.; Nicu, I.C.; Venedict, B. Cesium magnetometer survey in the Cucuteni settlement of Fulgeriș-La Trei Cireși, Bacău County, Romania. Rom. Rep. Phys. 2012, 64, 878-890.

15. Asăndulesei, A. Magnetic prospecting on Chalcolithic sites in north-eastern Romania: Some considerations regarding intr-site spatial organisation. Archaeol. Polona 2015, 53, 189-194.

16. Asăndulesei, A. Oblique air photography for Chalcolithic sites from Eastern Romania. Analysis and interpretation. Some examples. Studia Antiq. Archaeol. 2014, 20, 69-89.

17. Mischka, C. Geomagnetische Prospektion neolithischer und kupferzeitlicher Siedlungen in Rumänien. Eurasia Antiqua: Zeitschrift für Archäologie Eurasiens 2008, 14, 101-115.

18. Dumitroaia, G.; Ștefan, D.; Munteanu, R.; Garvăn, D.; Nicola, D. Investigații non-intruzive de la Poduri-Dealul Ghindaru. Mem. Antiq. 2012, XXVIII, 167-184.

19. Micle, D.; Măruia, L.; Oance, M.K.; Lazarovici, G.; Mantu, C.M.; Cîntar, A. Archaeological geomorphometry and geomorphography. Case study on Cucuteni sites from Ruginoasa and Scânteia, Iaşi County, Romania. Annales d'Université Valahia Târgovişte 2010, XII, 23-37. 
20. Asăndulesei, A.; Nicu, I.C.; Balaur, R.; Caliniuc, Ș.; Asăndulesei, M.; Cotiugă, V. Integrated prospection methods for documenting threatened prehistoric archaeological sites from north-eastern Romania. Archaeol. Polona 2015, 53, 425-430.

21. Nicu, I.C. Hydrogeomorphic Risk Analysis Affecting Chalcolithic Archaeological Sites from Valea Oii (Bahlui) Watershed, Northeastern Romania: An Interdisciplinary Approach; Springer: Cham, Switzerland, 2016.

22. Nicu, I.C.; Romanescu, G. Effect of natural risk factors upon the evolution of Chalcolithic human settlements in Northeastern Romania (Valea Oii watershed). From ancient times dynamics to present days degradation. Z. Geomorphol. 2016, 60,1-9. [CrossRef]

23. Romanescu, G.; Nicu, I.C. Risk maps for gully erosion processes affecting archaeological sites in Moldavia, Romania. Z. Geomorphol. 2014, 58, 509-523. [CrossRef]

24. Brigand, R.; Asăndulesei, A.; Weller, O.; Cotiugă, V. Notes préliminaires sur le peuplement chalcolithique des bassins hydrographiques du Bahluieţ et du Trestiana-Valea Oii (Iaşi). Dacia Revue d'Archéologie et d'Histoire Ancienne 2012, LVI, 5-32.

25. Tafrali, O. Stațiunea preistorică din punctul Boghiu. Arta și Arheologia 1936, 11-12.

26. Berlescu, N. Așezările cucuteniene de la Războieni și Prigorenii Mici. Studii și Cercetări Științifice 1955, VI/3-VI/4, 151-165.

27. Boghian, D. Comunitățile Cucuteniene din Bazinul Bahluiului; Editura Universității Ștefan cel Mare: Suceava, Romania, 2004.

28. Asăndulesei, A. Geophysical prospecting techniques used in archaeology. Magnetometry. Studia Antiq. Archeol. 2011, XVII, 5-17.

29. Asăndulesei, A. Aplicații ale metodelor geografice și geofizice în cercetarea interdisciplinară a așezărilor cucuteniene din Moldova. Studii de caz. Ph.D. Thesis, “Alexandru Ioan Cuza” University of Iași, Iași, Romania, 17 September 2012.

30. Aitken, M. Physics and Archaeology; Claredon Press: Oxford, UK, 1974.

31. Hesse, A. Prospections Géophysique à Faible Profondeur. Applications à L'archéologie; Dunod: Paris, France, 1966.

32. Scollar, I.; Tabbagh, A.; Hesse, A.; Herzog, I. Archaeological Prospecting and Remote Sensing; Cambridge University Press: Cambridge, UK, 1990.

33. Clark, A. Seeing Beneath the soil. Prospecting Methods in Archaeology; Routledge-Taylor \& Francis Group: Oxford, UK, 2001.

34. Gaffney, C.; Gater, J. Revealing the Buried Past: Geophysics for Archaeologists; Tempus: Gloucesternshire, UK, 2003.

35. David, A.; Linford, N.; Linford, P. Geophysical Survey in Archaeological Field Evaluation; English Heritage Publishing: Swindon, UK, 2008.

36. Gallo, D.; Ciminale, M.; Becker, H.; Masini, N. Remote sensing techniques for reconstructing a vast Neolithic settlement in Southern Italy. J. Archaeol. Sci. 2009, 36, 43-50. [CrossRef]

37. Sarris, A.; Papadopoulos, N.G.; Agapiou, A.; Salvi, M.C.; Hadjimitis, D.G.; Parkinson, W.A.; Yerkes, R.W.; Gyucha, A.; Duffy, P.R. Integration of geophysical surveys, ground hyperspectral measurements, aerial and satellite imagery for archaeological prospection of prehistoric sites: The case study of Vésztő-Mágor Tell, Hungary. J. Archaeol. Sci. 2013, 40, 1454-1470. [CrossRef]

38. Alexakis, D.; Sarris, A.; Astaras, T.; Albanakis, K. Integrated GIS, remote sensing and geomorphologic approaches for the reconstruction of the landscape habitation of Thessaly during the neolithic period. J. Archaeol. Sci. 2011, 38, 89-100. [CrossRef]

39. Stular, B.; Kokalj, Z.; Ostir, K.; Nuninger, L. Visualization of lidar-derived relief models for detection of archaeological features. J. Archaeol. Sci. 2012, 39, 3354-3360. [CrossRef]

40. Doneus, M. Openness as visualization technique for interpretative mapping of airborne LiDAR derived digital terrain models. Remote Sens. 2013, 5, 6427-6442. [CrossRef]

41. Kokalj, Ž.; Zakšek, K.; Oštir, K. Visualization of LiDAR derived relief models. In Interpreting Archaeological Topography: Airborne Laser Scanning, 3D Data and Ground Observation; Opitz, R.S., Cowley, D., Eds.; Oxbow Books: Oxford, UK, 2013; Volume 5, pp. 100-114.

42. Wilson, D.R. Air Photo Interpretation for Archaeologists; B.T. Batsford: London, UK, 1982.

43. Bewley, R.H. Aerial photography for archaeology. In Archaeological Method and Theory: An Encyclopedia; Ellis, L., Ed.; Garland Publishing: New York, NY, USA; London, UK, 2000; pp. 3-10. 
44. Palmer, R. Implicaţii ale arheologiei aeriene pentru arheologia din România. In Arheologie aeriană în România şi în Europa; Palmer, R., Târnoveanu, I.O., Bem, C., Eds.; Institutul de Memorie Culturală (CIMEC): Bucureşti, România, 2009; pp. 8-61.

45. Târnoveanu, I.O.; Bem, C. România: Un viitor pentru trecut. Fotografiile aeriene în repertorierea siturilor arheologice. In Arheologie Aeriană în România şi în Europa; Palmer, R., Târnoveanu, I.O., Bem, C., Eds.; Institutul de Memorie Culturală (CIMEC): Bucureşti, România, 2009; pp. 62-88.

46. Verhoeven, G.; Doneus, M.; Briese, C.; Vermuelen, F. Mapping by matching: A computer vision-based approach to fast and accurate georeferencing of archaeological aerial photographs. J. Archaeol. Sci. 2012, 39, 2060-2070. [CrossRef]

47. Atkinson, R.J.C. Field Archaeology; Methuen: London, UK, 1953.

48. Weymouth, J.W. Geophysical methods of archaeological site surveying. In Advances in Archaeological Method and Theory; Schiffer, M.B., Ed.; Academic Press: Cambridge, MA, USA, 1986; Volume 9, pp. 311-389.

49. Reynolds, J.M. An Introduction to Applied and Environmental Geophysics; John Wiley \& Sons: Hoboken, NJ, USA, 1997.

50. Linford, N. The application of geophysical methods to archaeological prospection. Rep. Prog. Phys. 2006, 69, 2205-2257. [CrossRef]

51. Kvamme, K.L. Geophysical surveys as landscape archaeology. Am. Antiq. 2003, 68, 435-457. [CrossRef]

52. Kvamme, K.L. Integrating multidimensional geophysical data. Archaeol. Prospect. 2006, 13, 57-72. [CrossRef]

53. Gaffney, C. Detecting trends in the prediction of the buried past: A review of geophysical techniques in archaeology. Archaeometry 2008, 50, 313-336. [CrossRef]

54. Oswin, J. A Field Guide to Geophysics in Archaeology; Praxis Publishing: Chichester, UK, 2009.

55. Piro, S. Introduction to geophysics for archaeology. In Seeing the Unseen: Geophysics and Landscape Archaeology; Campana, S., Piro, S., Eds.; CRC Press-Taylor \& Francis Group: London, UK, 2009; pp. 27-64.

56. Schmidt, A.; Ernenwein, E. Geophysical Data in Archaeology: A Guide to Good Practice, 2nd ed.; Archaeology Data Service: Oxford, UK, 2011.

57. Conyers, L.B. Ground-Penetrating Radar for Archaeology; AltaMira Press: Lanham, MD, USA, 2004.

58. Schmidt, A. Electrical and magnetic methods in archaeological prospection. In Seeing the Unseen: Geophysics and Landscape Archaeology; Campana, S., Piro, S., Eds.; CRC Press-Taylor \& Francis Group: London, UK, 2009; pp. 67-81.

59. Somers, L. Resistivity survey. In Remote Sensing in Archaeology: An Explicitly North American Perspective; Johnson, J.K., Ed.; University Alabama Press: Tuscaloosa, AL, USA, 2006; pp. 109-129.

60. Aspinall, A.; Gaffney, F.; Schmidt, A. Magnetometry for Archaeologists; AltaMira Press: Lanham, MD, USA, 2008.

61. Becker, H. From nanotesla to picotesla-A new window for magnetic prospecting in archaeology. Archaeol. Prospect. 1995, 2, 217-228.

62. Kvamme, K.L. Magnetometry: Nature's gift to archaeology. In Remote Sensing in Archaeology: An Explicitly North American Perspective; Johnson, J.K., Ed.; University Alabama Press: Tuscaloosa, AL, USA, 2006; pp. 205-233.

63. Becker, H. Caesium-magnetometry for landscape-archaeology. In Seeing the Unseen: Geophysics and Landscape Archaeology; Campana, S., Piro, S., Eds.; CRC Press-Taylor \& Francis Group: London, UK, 2009; pp. 129-165.

64. Becker, H. Duo- and quadro-sensor configuration for high speed/high resolution magnetic prospecting with caesium magnetometer. In Magnetic Prospecting in Archaeological Sites; Becker, H., Fassbinder, J.W.E., Eds.; International Council on Monuments and Sites (ICOMOS): Munich, Germany, 2001; pp. 20-25.

65. Fassbinder, J.W.E. Seeing beneath the farmland, steppe and desert soil: Magnetic prospecting and soil magnetism. J. Archaeol. Sci. 2015, 56, 85-95. [CrossRef]

66. Cotiugă, V. Locuințele Eneolitice de pe Teritoriul României; Editura Universității “Alexandru Ioan Cuza" din Iași: Iași, România, 2015.

67. Neubauer, W. GIS in archaeology-The interface between prospection and excavation. Archaeol. Prospect. 2004, 11, 159-166. [CrossRef]

68. Popovici, D.N. Cultura Cucuteni, Faza A. Repertoriul Așezărilor; Editura Constantin Matasă: Piatra-Neamț, Romania, 2000.

69. Fassbinder, J.W.E. Magnetometry for archaeology. In Encyclopedia of Geoarchaeology, Encycl. Earth Sci. Series; Gilbert, A., Ed.; Springer: Dordrecht, The Netherlands, 2016; pp. 499-514. 
70. Fassinder, J.W.E.; Stanjek, H.; Vali, H. Occurrence of magnetic bacteria in soil. Nature 1990, 343, $161-163$. [CrossRef] [PubMed]

71. Fassinder, J.W.E.; Stanjek, H. Occurrence of bacterial magnetite in soils from archaeological sites. Archeolo. Polona 1993, 31, 117-128.

72. Bîlcu, S.M. Considerații pe marginea organizării interne a unora dintre așezările culturilor din complexul Precucuteni-Cucuteni. Cultură și civilizație la Dunărea de Jos 1997, XV, 165-201.

73. Sorochin, V. Modalități de organizare a așezărilor complexului cultural Cucuteni-Tripolie. Arheol. Mold. 1993, XVI, 69-86.

74. Sorochin, V. Considerații referitoare la așezările Cucuteni A-Tripolie B1 din Ucraina și Republica Moldova. Mem. Antiq. 1997, XXI, 8-83.

75. Chitic, O. Elements d'habitat de la periode Cucuteni A et Cucuteni A-B de l'espace pruto-dniestreen. In Etablissements et Habitations Prehistoriques. Structure, Organisation, Symbole. Actes du Colloque de Iași 10-12 Decembre 2007; Chirica, V., Văleanu, M.C., Eds.; Editura Pim: Iași, România, 2008; pp. 263-314.

76. Rassmann, K.; Mertl, P.; Voss, H.U.; Bicbaev, V.; Popa, A.L.; Musteață, S. Copper Age settlements in Moldova: Insights into a complex phenomenon from recent geomagnetic surveys. In Trypillia Mega-Sites and European Prehistory 4100-3400 BCE; Müller, J., Rassmann, K., Videiko, M., Eds.; Routledge: New York, NY, USA, 2016; pp. 55-69.

77. Chapman, J.; Videiko, M.; Hale, D.; Gaydarska, B.; Burdo, N.; Rassman, K.; Mischka, C.; Müller, J.; Piotrovskiy, A.K.; Kruts, V. The second phase of Trypillia mega-site methodological revolution: A new research agenda. Eur. J. Archaeol. 2014, 17, 369-406. [CrossRef]

78. Videiko, M. Looking for Trypillya Culture Proto-Cities, Author's Edition ed; Kiev, Ukraine, 2005; Available online: http:/ /www.academia.edu/7417015/Looking_for_Trypillya_Culture_proto-cities_2005_(accessed on 5 January 2017).

79. Dîmbovița, M.P.; Văleanu, M.C. Cucuteni-Cetățiie, Monografie Arheologică; Editura "Constantin Matasă”: Piatra Neamt, România, 2004.

80. Bem, C. Traian-Dealul Fântânilor, Fenomenul Cucuteni A-B; Editura Cetatea de Scaun: Târgoviște, România, 2007.

81. Matasă, C. Frumuşica. Village Préhistorique à Céramique Peinte dans la Moldavie du nord, Roumanie; Imprimeria Națională: Bucureşti, România, 1946.

82. Chapman, J.; Videiko, M.; Gaydarska, B.; Burdo, N.; Hale, D. Architectural differentiation on a Trypillia mega-site: Preliminary report on the excavation of a mega-structure at Nebelivka, Ukraine. J. Neolit. Archaeol. 2014, 16, 135-156.

83. Rassmann, K.; Piotrovskiy, A.K.; Videiko, M.; Müller, J. The new challenge for site plans and geophysics: Revealing the settlement structure of giant settlements by means of geomagnetic survey. In Trypillia Mega-Sites and European Prehistory 4100-3400 BCE; Müller, J., Rassmann, K., Videiko, M., Eds.; Routledge: New York, NY, USA, 2016; pp. 29-54.

84. László, F. Fouilles à la station primitive de Erősd (1907-1912). Dolgozatok 1914, V, 387-417.

(C) 2017 by the author; licensee MDPI, Basel, Switzerland. This article is an open access article distributed under the terms and conditions of the Creative Commons Attribution (CC-BY) license (http:/ / creativecommons.org/licenses/by/4.0/). 